\title{
Thermal Expansion of Aluminum and Some Aluminum Alloys
}

\author{
Peter Hidnert and H. S. Krider
}

\begin{abstract}
Data are given on the linear thermal expansion of aluminum and some aluminumberyllium, aluminum-copper, aluminum-sillcon, aluminum-copper-iron, aluminum-coppermagnesium, aluminum-copper-nickel, aluminum-silicon-copper, aluminum-silicon-magnesium, aluminum-copper-nickel-magnesium, aluminum-copper-tin-zinc, aluminum-siliconcopper-manganese, aluminum-silicon-copper-nickel, aluminum-silicon-nickel-copper-manganese, and aluminum-silicon-nickel-copper-molybdenum alloys for various temperature ranges between $-50^{\circ}$ and $+400^{\circ} \mathrm{C}$. The addition of beryllium, copper, or silicon to aluminum causes a decrease in the coefficients of expansion. Copper has a greater effect than beryllium, and silicon has the greatest effect of these three alloying elements. Ternary diagrams are shown that indicate the effects of composition on the coefficients of expansion of aluminumcopper-nickel and aluminum-silicon-copper alloys. The effects of additions of two or three elements (copper, nickel, manganese, and molybdenum) on the coefficients of expansion of aluminum-silicon alloys are indicated in a figure.
\end{abstract}

\section{Introduction}

Data on the linear thermal expansion of the samples of aluminum and of some aluminum alloys (binary, ternary, quaternary, etc.) listed in table 1 were obtained during the past quarter of a century. ${ }^{1}$ These results are based on a number of independent tests and investigations, the specific purposes of which in general were not related.

It is the object of this paper to report coefficients of expansion during heating and cooling of the samples for various temperature ranges between $-50^{\circ}$ and $+400^{\circ} \mathrm{C}$ and to establish correlations between the coefficients of expansion and the chemical composition of the annealed aluminum alloys.

\section{Materials Investigated}

The samples of aluminum and of aluminum alloys were obtained from Aluminum Company of America, Cleveland, Ohio and New Kensington, Pa., Brush Beryllium Co., Cleveland, Ohio, Bureau of Aeronautics, Navy Dept., Washington, D. C., CooperWilford Beryllium Co., Philadelphia, Pa., National Advisory Committee for Aeronautics, Washington, D. C., and Naval Aircraft Factory, Philadelphia, Pa. The length of each sample used in the determinations of linear thermal expansion was $200 \mathrm{~mm}$ (7.9 in.) for the range from $-50^{\circ}$ to $+20^{\circ}$ C. and $300 \mathrm{~mm}$ (11.8 in.) for the range from $+20^{\circ}$ to $400^{\circ} \mathrm{C}$. The cross sections of the samples, their treatments, and chemical compositions are given in table $1 .^{2}$ Most of the values for chemical composition were furnished by the manufacturers or organizations that submitted the samples.

\section{Apparatus}

The fused-quartz tube and dial-indicator method and the precision micrometric method were used for determinations of linear thermal expansion of the samples for the ranges from $-50^{\circ}$ to $+20^{\circ} \mathrm{C}$ and

1 W. T. Sweeney of the Bureau assisted the senior author during the early work. 2 Figures in brackets indicate the literature references at the end of this paper. from $+20^{\circ}$ to $400^{\circ} \mathrm{C}$, respectively. These methods were described by Hidnert and Souder [3].

\section{Results and Discussion}

Expansion curves on heating and on cooling were plotted from the observations on the samples of aluminum and aluminum alloys at various temperatures between $-50^{\circ}$ and $+400^{\circ} \mathrm{C}$. Table 1 gives coefficients of expansion and coefficients of contraction that were computed from these curves, some of which are shown in figures 5 to 9 , inclusive. The last column of the table shows, for most of the samples, the changes in length (at room temperature) that occurred as a result of the heating and cooling in the thermal-expansion tests.

Table 1, A, gives coefficients of expansion of two samples of cast aluminum and two samples of annealed aluminum. The coefficients of expansion of the samples of annealed aluminum are slightly less than the coefficients for cast aluminum.

Table 2 gives a comparison of coefficients of expansion of annealed aluminum in the present investigation, with those determined by Nix and MacNair [4] and Taylor, Willey, Smith, and Edwards [5] by the interference method. Taylor and his coworkers indicated that recrystallization and grain growth, or changes at the interfaces between specimen and the interferometer plates, such as growth of the oxide film on the aluminum, are some of the sources of error.

Table 1, B, gives coefficients of expansion of three aluminum-beryllium alloys containing 35,40 , and 71 percent of beryllium by weight $(62,67$, and 88 atomic percent).

Figure 1 indicates coefficients of expansion for aluminum-beryllium alloys of the present investigation and those obtained by Hidnert and Sweeney [6] in a previous investigation, for the ranges $20^{\circ}$ to $100^{\circ} \mathrm{C}$ and $20^{\circ}$ to $300^{\circ} \mathrm{C}$. The coefficients of expansion obtained in the second heating are indicated in the figure and represent values for annealed alloys. The coefficients of expansion obtained in the first heating of the cast alloy (sample 1630) containing 
TABLE 1. Coefficients of linear expansion of aluminum and some aluminum alloys

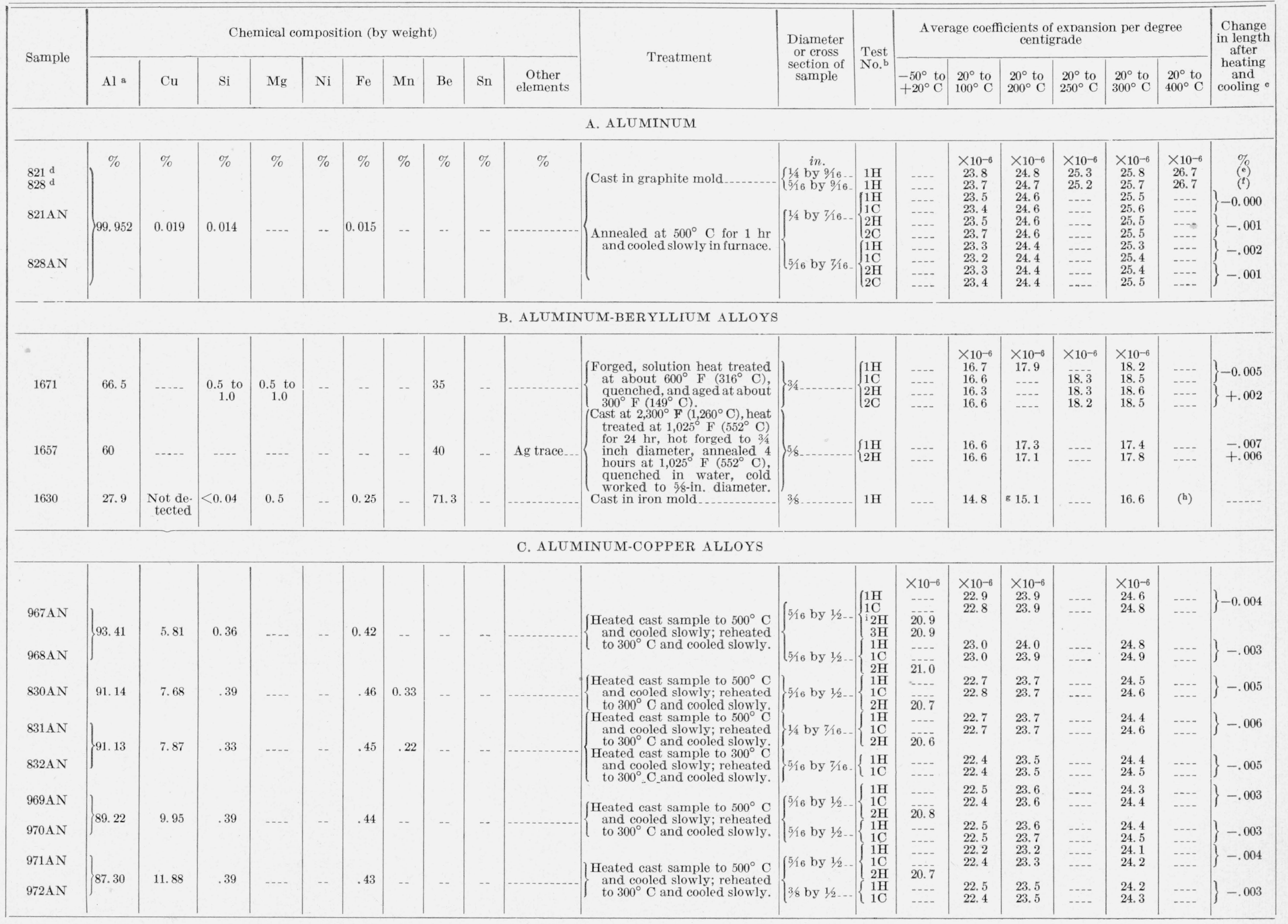




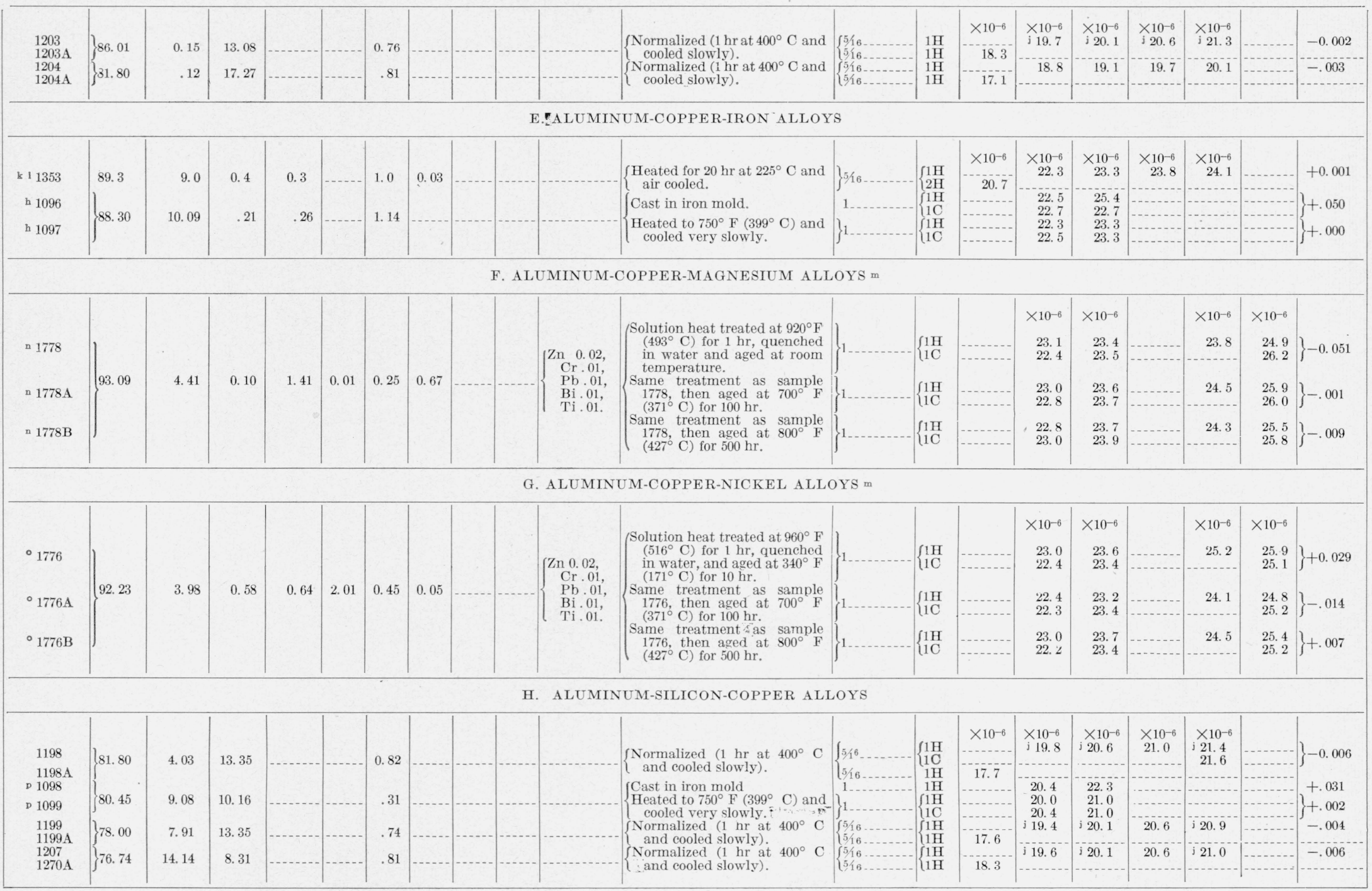

See footnotes at end of table. 
TABLE 1. Coefficients of linear expansion of aluminum and some aluminum alloys-Continued

\begin{tabular}{|c|c|c|c|c|c|c|c|c|c|c|c|c|c|c|c|c|c|c|c|c|}
\hline \multirow{2}{*}{ Sample } & \multicolumn{10}{|c|}{ Chemical composition (by weight) } & \multirow{2}{*}{ Treatment } & \multirow{2}{*}{$\begin{array}{l}\text { Diameter } \\
\text { or cross } \\
\text { section of } \\
\text { sample }\end{array}$} & \multirow{2}{*}{$\begin{array}{l}\text { Test } \\
\text { No. } \\
\end{array}$} & \multicolumn{6}{|c|}{$\begin{array}{l}\text { A verage coefficients of expansion per degree } \\
\text { centigrade }\end{array}$} & \multirow{2}{*}{$\begin{array}{l}\text { Change } \\
\text { in length } \\
\text { after } \\
\text { heating } \\
\text { and } \\
\text { cooling }\end{array}$} \\
\hline & $\mathrm{Al} \approx$ & $\mathrm{Cu}$ & $\mathrm{Si}$ & $\mathrm{Mg}$ & $\mathrm{Ni}$ & $\mathrm{Fe}$ & Mn & $\mathrm{Be}$ & Sn & $\begin{array}{l}\text { Other } \\
\text { elements }\end{array}$ & & & & $\begin{array}{l}-50^{\circ} \text { to } \\
+20^{\circ} \mathrm{C}\end{array}$ & $200^{\circ}$ to & $200^{\circ}$ to $\mathrm{C}$ & $250^{\circ} \stackrel{\text { to }}{\mathrm{C}}$ & $300^{\circ}$ to $\mathrm{C}$ & $\begin{array}{l}20^{\circ} \text { to } \\
400^{\circ} \mathrm{C}\end{array}$ & \\
\hline \multicolumn{21}{|c|}{ I. ALUMINUM-SILICON-MAGNESIUM ALLOYS m } \\
\hline a $1779 \mathrm{~A}$ & 84.40 & 0.89 & 12. 18 & 1.20 & 0.87 & 0.41 & 0.01 & & & $\left\{\begin{array}{l}\text { Zn } 0.02 \\
\text { Cr .01, } \\
\text { Ti .01. }\end{array}\right.$ & $\left\{\begin{array}{l}\text { Solution heat treated at } 960^{\circ} \mathrm{F} \\
\left(516^{\circ} \mathrm{C}\right) \text { for } 1 \mathrm{hr} \text {, quenched } \\
\text { in water, aged at } 340^{\circ} \mathrm{F} \\
\left(171^{\circ} \mathrm{C} \text { ) for } 12 \mathrm{hr} \text {. }\right. \\
\text { Same treatment as sample } \\
1779, \text { then aged at } 700^{\circ} \mathrm{F} \\
\left(371^{\circ} \mathrm{C}\right) \text { for } 100 \mathrm{hr} \text {. } \\
\text { Same treatment as sample } \\
1779, \text { then aged at } 800^{\circ} \mathrm{F} \\
\left.427^{\circ} \mathrm{C}\right) \text { for } 500 \mathrm{hr} \text {. }\end{array}\right.$ & $\left\{\begin{array}{l}1 \ldots \\
1 \ldots\end{array}\right.$ & $\left\{\begin{array}{l}1 \mathrm{H} \\
\mathrm{IC} \\
\{1 \mathrm{H} \\
1 \mathrm{C} \\
1 \mathrm{H} \\
1 \mathrm{C}\end{array}\right.$ & & $\begin{array}{l}\times 10^{-6} \\
20.0 \\
18.6 \\
\\
19.8 \\
19.4 \\
18.6\end{array}$ & $\begin{array}{l}\times 10^{-6} \\
21.1 \\
19.8 \\
\\
20.4 \\
20.5 \\
19.6\end{array}$ & & $\begin{array}{l}\times 10^{-6} \\
22.4 \\
20.8 \\
20.3 \\
21.0\end{array}$ & $\begin{array}{l}\times 10^{-6} \\
23.2 \\
21.6 \\
\\
21.5 \\
21.3 \\
21.8 \\
21.3\end{array}$ & $\begin{array}{l}\}+0.063 \\
\}+.022 \\
\}+.021\end{array}$ \\
\hline \multicolumn{21}{|c|}{ J. ALUMINUM-COPPER-NICKEL-MAGNESIUM ALLOYS m } \\
\hline $\begin{array}{l}\text { × } 1777 \\
\therefore 1777 \mathrm{~A}\end{array}$ & 91.56 & 3. 89 & 0.58 & 1.43 & 2. 14 & 0.31 & 0.01 & & & $\left\{\begin{array}{c}\mathrm{Zn} 0.02 \\
\mathrm{Cr} .01 \\
\mathrm{~Pb} .01 \\
\mathrm{Bi} .01 \\
\mathrm{Ti} .03 \\
-\quad\end{array}\right.$ & $\left\{\begin{array}{l}\text { Solution heat treated at } 960^{\circ} \mathrm{F} \\
\times\left(516^{\circ} \mathrm{C}\right) \text { for } 1 \mathrm{hr} \text {, quenched } \\
\text { in water, aged at } 340^{\circ} \mathrm{F} \\
\left.171^{\circ} \mathrm{C}\right) \text { for } 10 \mathrm{hr} \text {. } \\
\text { Same treatment as sample } \\
1777, \text { then aged at } 700^{\circ} \mathrm{F} \\
\left(371^{\circ} \mathrm{C}\right) \text { for } 100 \mathrm{hr} \text {. }\end{array}\right.$ & & $\left\{\begin{array}{l}1 \mathrm{H} \\
1 \mathrm{C} \\
1 \mathrm{H} \\
1 \mathrm{C}\end{array}\right.$ & & $\begin{array}{l}\times 10^{-6} \\
23.0 \\
22.6 \\
\\
22.6 \\
22.6\end{array}$ & $\begin{array}{l}\times 10^{-6} \\
23.4 \\
23.6 \\
\\
24.1\end{array}$ & & $\begin{array}{l}\times 10^{-6} \\
24.4 \\
24.3 \\
24.3\end{array}$ & $\begin{array}{l}\times 10^{-6} \\
25.9 \\
25.1 \\
\\
25.1 \\
25.0\end{array}$ & $\begin{array}{l}\}+0.039 \\
\}+.002\end{array}$ \\
\hline \multicolumn{21}{|c|}{ K. ALUMINUM-COPPER-TIN-ZINC ALLOYS } \\
\hline $\begin{array}{l}\text { 't } 1649 \\
. \quad 1649 \mathrm{~A} \\
. \mathrm{t} 1649 \mathrm{~B}\end{array}$ & 94.0 & 1.8 & 0.2 & 0.6 & & 0.6 & 0.02 & & 1.3 & $\left\{\begin{array}{l}\mathrm{Zn} 1.1 \\
\mathrm{Cr} 0.2 \\
\mathrm{Ti}\end{array}\right.$ & $\left\{\begin{array}{l}\text { Sand east. } \\
\text { Heated to } 650^{\circ} \mathrm{F}\left(343^{\circ} \mathrm{C}\right) \text {, held } \\
\text { for } 2 \text { hrs and cooled slowly in } \\
\text { furnace. } \\
\text { Same treatment as sample } \\
1649 \mathrm{~A} \text {. }\end{array}\right.$ & & $\left\{\begin{array}{l}1 \mathrm{H} \\
1 \mathrm{C} \\
1 \mathrm{H} \\
1 \mathrm{C} \\
1 \mathrm{H}\end{array}\right.$ & \begin{tabular}{c|}
$\times 10^{-0}$ \\
21.6
\end{tabular} & \begin{tabular}{l}
$\times 10^{-6}$ \\
23.3 \\
\hdashline 22.8 \\
23.2
\end{tabular} & $\begin{array}{l}\times 10^{-6} \\
24.6 \\
24.0 \\
24.2\end{array}$ & \begin{tabular}{c}
$\times 10^{-6}$ \\
25.4 \\
24.6 \\
- \\
\hdashline$-1 .-$
\end{tabular} & \begin{tabular}{c}
$\times 10^{-6}$ \\
\hdashline 25.1 \\
25.1
\end{tabular} & & $\left\{\begin{array}{l}+0.022 \\
-.000\end{array}\right.$ \\
\hline \multicolumn{21}{|c|}{ L. ALUMINUM-SILICON-COPPER-MANGANESE ALLOY } \\
\hline $\begin{array}{l}1205 \\
1205 \mathrm{~A}\end{array}$ & 74.50 & 3.18 & 20. 29 & & & 0.96 & 1.07 & & & & $\left\{\begin{array}{c}\text { Normalized }\left(1 \mathrm{hr} \text { at } 400^{\circ} \mathrm{C} \text { and }\right. \\
\text { cocled slowly). }\end{array}\right.$ & $\left\{\begin{array}{l}5 / 16 \ldots \ldots \\
5 / 16 \ldots\end{array}\right.$ & $\begin{array}{l}1 \mathrm{H} \\
1 \mathrm{H}\end{array}$ & \begin{tabular}{c}
$\times 10^{-6}$ \\
\hdashline 15.9
\end{tabular} & $\begin{array}{l}\times 10^{-6} \\
j 17.4\end{array}$ & $\begin{array}{l}\times 10^{-6} \\
\text { i } 18.0\end{array}$ & $\begin{array}{l}\times 10^{-6} \\
18.5\end{array}$ & $\begin{array}{l}\times 10^{-6} \\
j 18.8\end{array}$ & & +0.002 \\
\hline
\end{tabular}


M. ALUMINUM-SILICON-COPPER-NICKEL ALLOYS

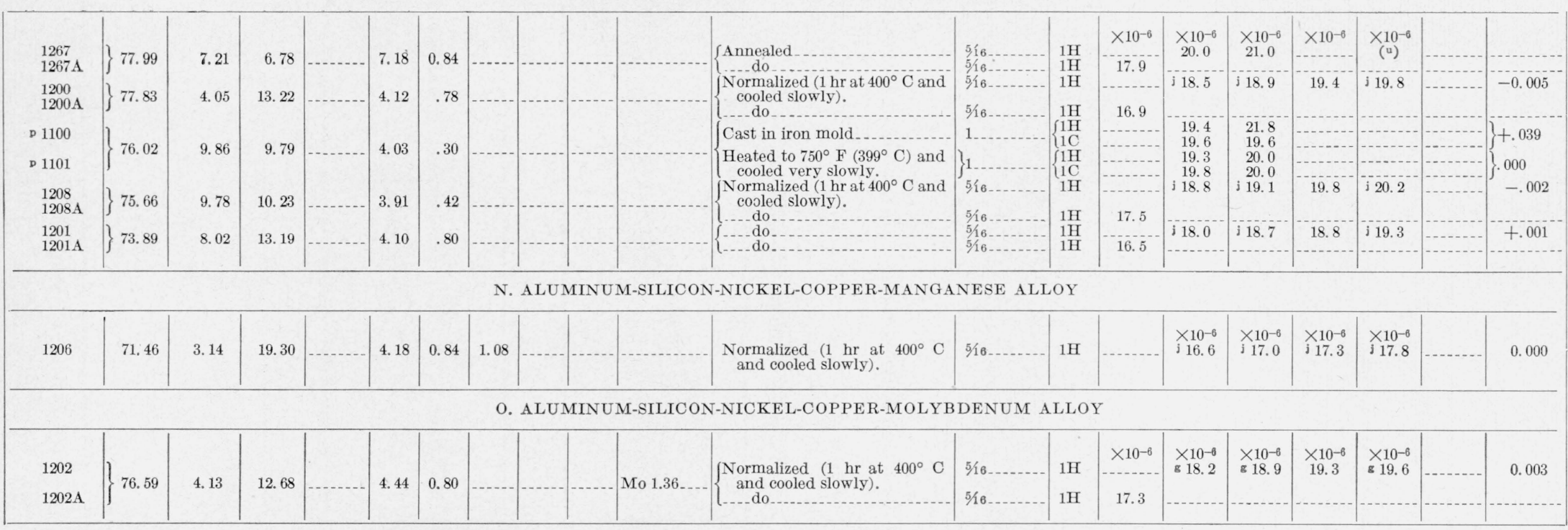

a Aluminum by difference (except for sample 1630 on which beryllium was determined by difference). b H indicates that the coefficients of expansion were obtained on heating and $\mathrm{C}$ on cooling. on cooling. The plus sign indicates an increase in length and the minus sign a decrease in length

- After heating to $618^{\circ} \mathrm{C}$ and cooling to room temperature, sample was about $0.01 \%$ longer than the length before heating.
After heating to $609^{\circ} \mathrm{C}$ and cooling to room temperature, sample was about $0.02 \%$ longer than the length before heating.

usly (through J. B. Johnson) in Rev. Sci. Instr. 12, 286 (1941).

s. Published previously (through J. B. Johnson) in Rev. Sci.
h Between $20^{\circ}$ and $350^{\circ} \mathrm{C}$, coefficient of expansion $17.3 \times 10^{-6}$

Before this test, sample was cooled to $-50^{\circ} \mathrm{C}$ and heated to $+20^{\circ} \mathrm{C}$.

Determined in 1926 by P. Hidnert and W. T. Sweeney of the National Bureau of Standards and published in 1933 by Kempf [?

1 Chemical composition was determined by spectrographic analysis by the Spectrochemistry Section of the Bureau.

The samples were rolled before the heat treatments.

- Trade name, $24 \mathrm{~S}$ alloy.

Dodified by the Alpax process.

a Trade name, $32 \mathrm{~S}$ alloy.

s Aluminum alloy Al-31, Navy A ronautical Specification M-397 (Mar 15, 1940)

Chemical composition was determined by chemical and spectrochemical analysis by the Chemistry

Division of the National Bureau of Standards.
u Sample bent slightly between $200^{\circ}$ and $300^{\circ} \mathrm{C}$. 
TABLE 2. Comparison of coefficients of linear expansion of annealed aluminum

\begin{tabular}{|c|c|c|c|c|c|c|}
\hline \multirow{2}{*}{ Observer } & \multirow{2}{*}{ Date } & \multirow{2}{*}{$\begin{array}{l}\text { Purity of } \\
\text { aluminum }\end{array}$} & \multicolumn{4}{|c|}{ A verage coefficients of expansion per degree centigrade } \\
\hline & & & $20^{\circ}$ to $100^{\circ} \mathrm{C}$ & $20^{\circ}$ to $200^{\circ} \mathrm{C}$ & $20^{\circ}$ to $300^{\circ} \mathrm{C}$ & $20^{\circ}$ to $400^{\circ} \mathrm{C}$ \\
\hline $\begin{array}{l}\text { Nix and MacNair } \\
\text { Taylor, Willey, Smith, and } \\
\text { Edwards. } \\
\text { Hidnert and Krider }\end{array}$ & $\begin{array}{l}1941 \\
1938\end{array}$ & $\begin{array}{l}\text { Percent } \\
99.997 \\
99.996\end{array}$ & $\begin{array}{l}23.9 \times 10^{-6} \\
\text { a } 23.9\end{array}$ & $\begin{array}{l}24.3 \times 10^{-6} \\
\text { จ } 24.6\end{array}$ & $\begin{array}{l}25.3 \times 10^{-6} \\
\text { a } 25.45 \\
\text { b } 25.5\end{array}$ & $\begin{array}{l}26.5 \times 10^{-6} \\
\text { a } 26.5\end{array}$ \\
\hline Mean & & & 23.7 & 24.5 & 25.4 & 26.5 \\
\hline
\end{tabular}

a Average value for 3 specimens.

b Average value for 2 samples (total of 8 determinations on heating and cooling).

the highest content of beryllium and mean values ${ }^{3}$ for annealed aluminum ( $0 \%$ of beryllium) are included in the figure. This figure shows that the addition of beryllium to aluminum decreases the coefficients of expansion. The relation between the chemical composition (atomic percent) and the coefficients of expansion for each temperature range is approximately linear, ${ }^{4}$ which is in agreement with the theory

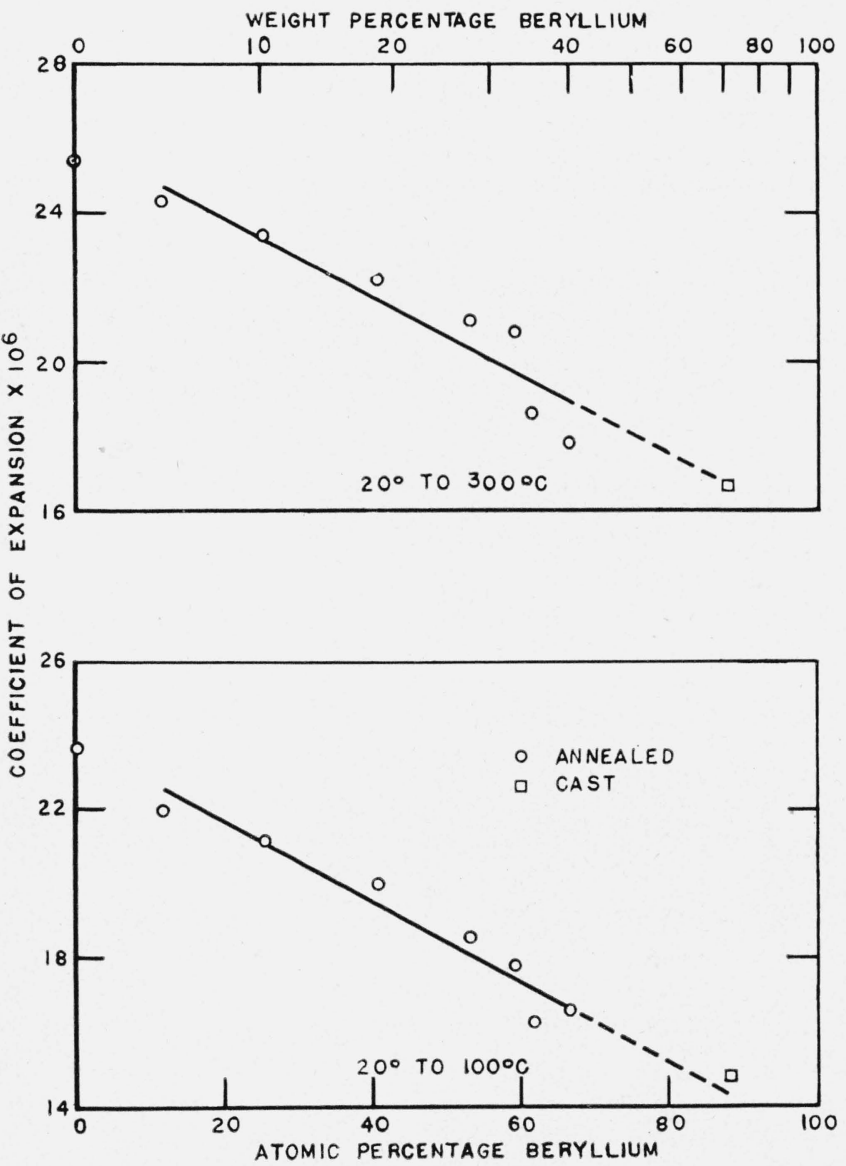

Figure 1. Coefficients of linear thermal expansion of aluminum-beryllium alloys.

A verage values for aluminum taken from table 2.

${ }^{3}$ From table 2 .

${ }_{4}^{4}$ In figures 1 to 4 , the straight lines were not extended to 0 atomic percent because there are solid solutions near this percentage. for the eutectiferous portion of the equilibrium diagram [7] for aluminum-beryllium alloys.

Table 1, C, gives coefficients of expansion of nine samples of annealed aluminum-copper alloys containing from 5.8 to 11.9 percent of copper by weight (2.6 to 5.4 atomic percent). For each sample, the coefficients of expansion on heating agree closely with the corresponding coefficients on cooling. The maximum deviation is $\pm 0.2 \times 10^{-6}$.

Figure 2 shows the relations between the chemical composition (atomic percent of copper) of annealed aluminum-copper alloys and the average coefficients of expansion for three temperature ranges on heating. This figure includes coefficients of expansion obtained by Bollenrath [8], Kempf [2], and Willey and Fink [9] on annealed aluminum-copper alloys and mean values (table 2) on annealed aluminum ( $0 \%$ of copper).

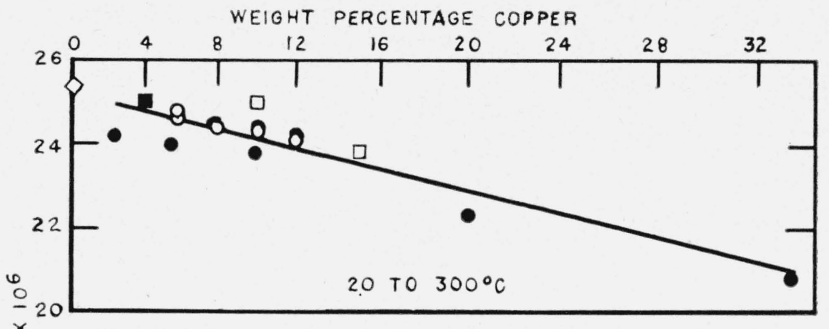

$z$
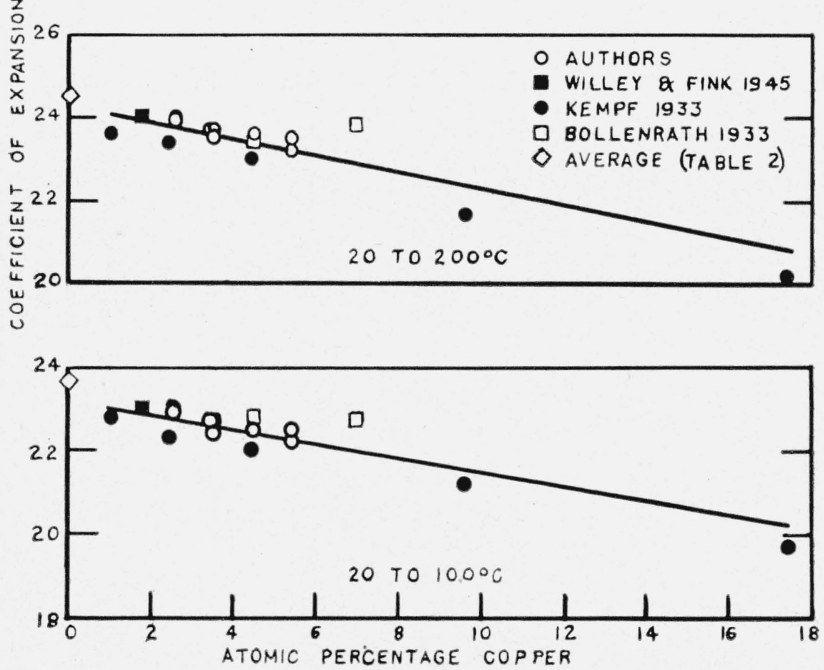

Figure 2. Coefficients of linear thermal expansion of annealed aluminum-copper alloys. 
The values for annealed aluminum-copper alloys for each temperature range may be represented by a
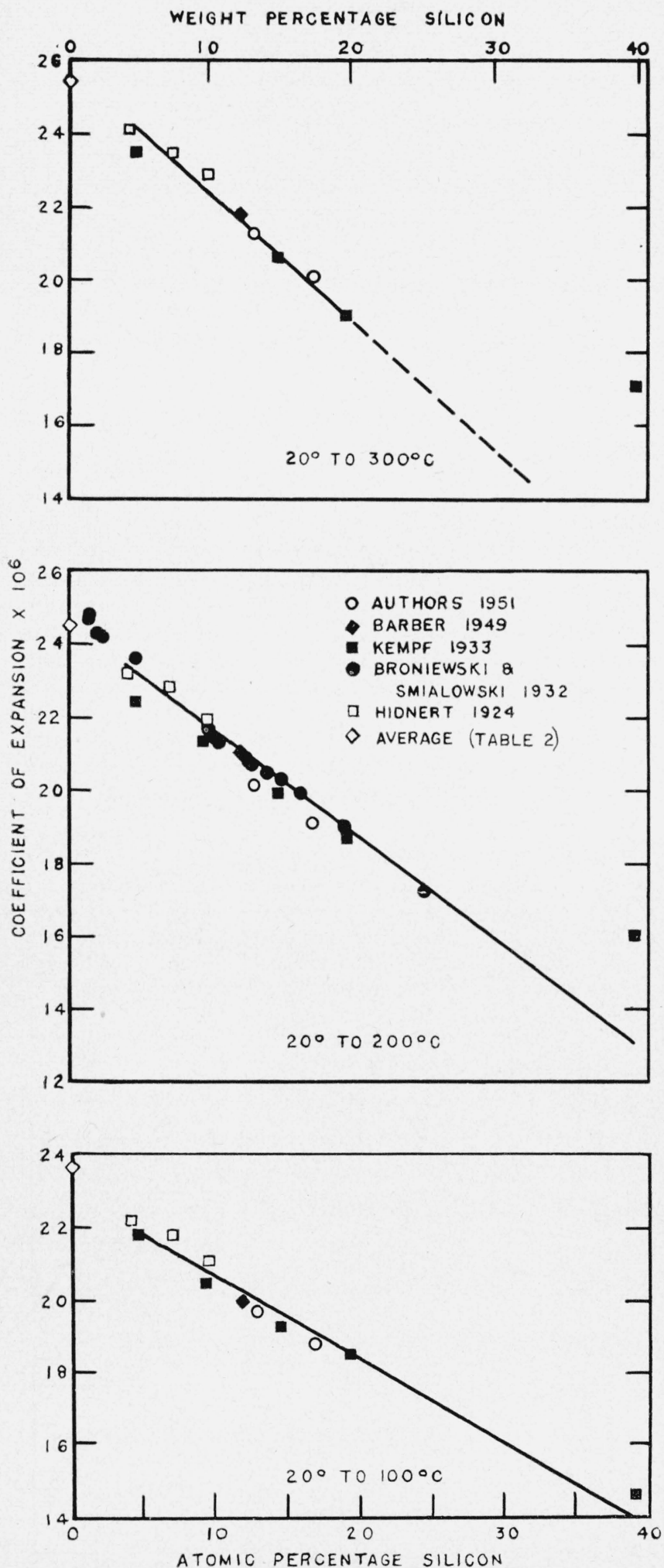

FIGURE 3. Coefficients of linear thermal expansion of annealed aluminum-silicon alloys. straight line and indicate that the coefficient of expansion decreases with increase in the atomic percent of copper. A linear relation is to be expected between the chemical composition (atomic percent) and the coefficients of expansion of these alloys represented by the eutectiferous portion of the aluminum end of the aluminum-copper equilibrium diagram [10].

Figure 3 shows the average coefficients of expansion of two samples of annealed aluminum-silicon alloys in table 1, D, and the coefficients of expansion of other annealed aluminum-silicon alloys investigated by Hidnert [1], Broniewski and Smialowski [11], Kempf [2], and Barber [12], for three temperature ranges. The silicon content of the alloys range from 1.3 to 40 percent by weight (1.2 to 39 atomic percent). As Broniewski and Smialowski appeared to have made measurements only at room temperature, the boiling point of naphthalene $\left(218^{\circ} \mathrm{C}\right)$, and at liquidair temperature [13], the coefficients of expansion ${ }^{5}$ that were computed from their data for the range $20^{\circ}$ to $200^{\circ} \mathrm{C}$ only, are shown in figure 3 .

The relation between the chemical composition (atomic percent) of these eutectiferous alloys [14] and the coefficients of expansion for each temperature
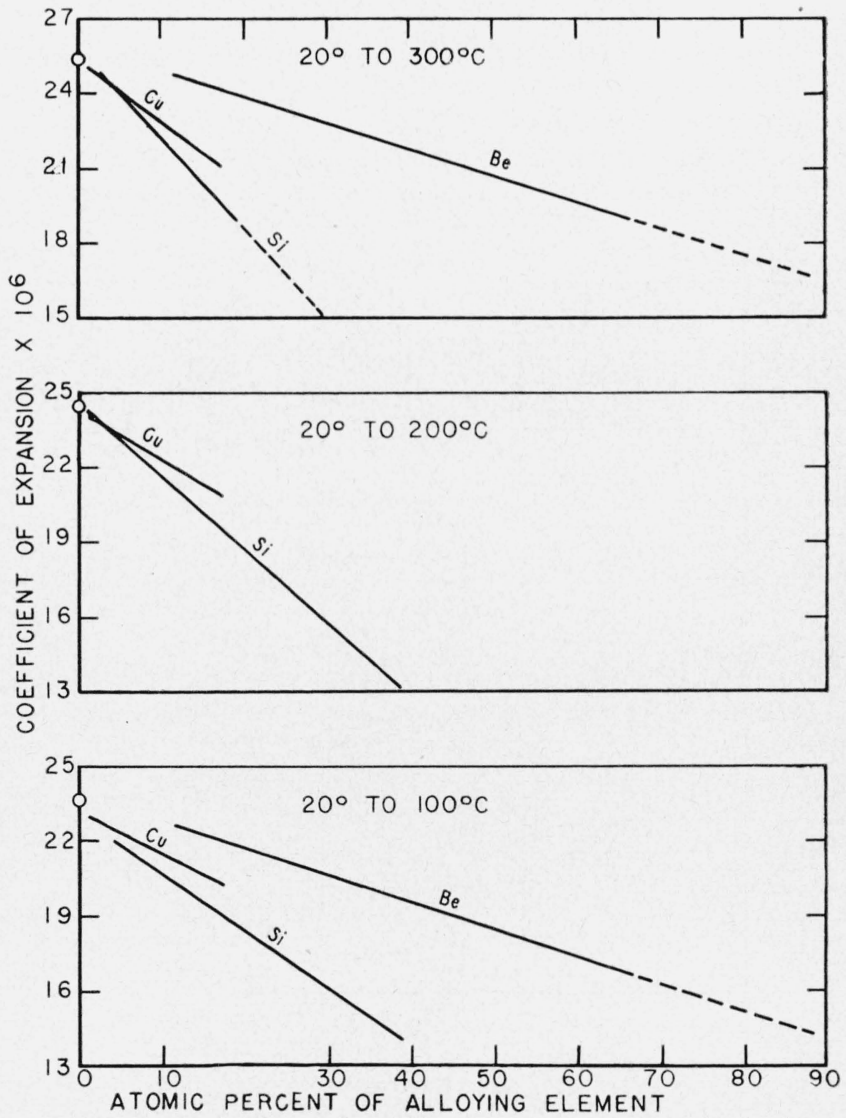

Figure 4. Effects of beryllium, copper, and silicon on coefficients of linear thermal expansion of aluminum.

${ }^{5}$ For alloys containing from 1.2 to 24.4 atomic percent of silicon. The present authors estimated that these alloys contained less than 1 percent of iron. 
TABLE 3. Coefficients of expansion of annealed aluminum-iron and aluminum-copper-iron alloys by other observers

\begin{tabular}{|c|c|c|c|c|c|c|}
\hline \multirow{2}{*}{ Observer } & \multirow{2}{*}{ Date } & \multicolumn{2}{|c|}{$\begin{array}{l}\text { Chemical composition } \\
\text { (by weight) }\end{array}$} & \multicolumn{3}{|c|}{$\begin{array}{l}\text { A verage coefficients of expansion per } \\
\text { degree centigrade }\end{array}$} \\
\hline & & $\mathrm{Cu}$ & $\mathrm{Fe}$ & $20^{\circ}$ to $100^{\circ} \mathrm{C}$ & $20^{\circ}$ to $200^{\circ} \mathrm{C}$ & $20^{\circ}$ to $300^{\circ} \mathrm{C}$ \\
\hline $\begin{array}{l}\text { Kempf } \\
\text { Maresca } \\
\text { Kempf }\end{array}$ & $\begin{array}{l}1933 \\
1936 \\
1933\end{array}$ & $\begin{array}{l}3.22 \\
9.77 \\
9.88\end{array}$ & $\begin{array}{l}\% \\
4.45 \\
8.46 \\
1.47 \\
5.04 \\
1.06\end{array}$ & $\begin{array}{l}\text { 20. } 4 \times 10^{-6} \\
21.0 \\
19.9 \\
21.2\end{array}$ & $\begin{array}{l}22.3 \times 10^{-6} \\
21.5\end{array}$ & $\begin{array}{l}23.3 \times 10^{-6} \\
22.3 \\
\text { a } 23.3 \\
21.5 \\
22.7\end{array}$ \\
\hline
\end{tabular}

a $20^{\circ}$ to $275^{\circ} \mathrm{C}$.

range may be represented by a straight line ${ }^{6}$ similar to the linear relations indicated in figures 1 and 2 for the eutectiferous aluminum-beryllium and aluminum-copper alloys. The coefficients of expansion of the aluminum-silicon alloys for the three temperature ranges decrease with increase in the atomic percent of silicon.

It has been shown that the addition of beryllium, copper, or silicon to aluminum causes a decrease in the coefficients of expansion. Figure 4 shows a comparison of the effects of these alloying elements (atomic percent) for three temperature ranges. Copper has a greater effect than beryllium, and silicon has the greatest effect of these three alloying elements.

Table 1, E, gives average coefficients of expansion of three samples of aluminum-copper-iron alloys containing 9 and 10 percent of copper and 1 percent of iron by weight, respectively. The expansion curve (fig. 5) of cast sample 1096 shows a marked increase

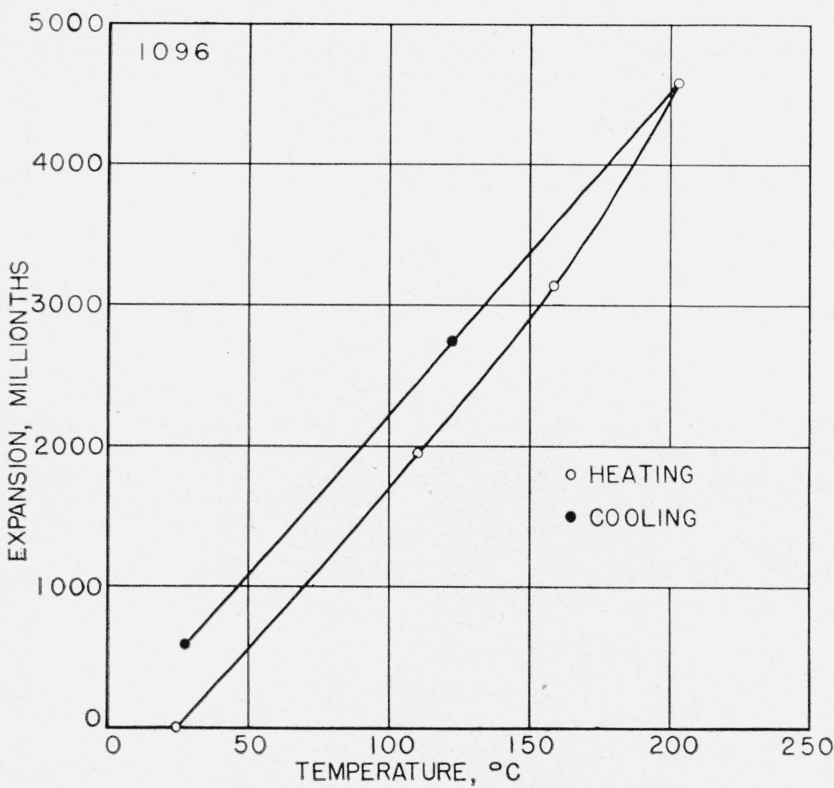

Figure 5. Linear thermal expansion (in millionths per unit length) of cast aluminum-copper-iron alloy containing 10.1 percent of copper and 1.1 percent of iron by weight.

${ }^{6}$ In deriving the straight line for the range $20^{\circ}$ to $300^{\circ} \mathrm{C}$, the authors ignored Kemp's value for the coefficient of expansion of the aluminum-silicon alloy containing the highest content of silicon. in the rate of expansion on heating between $150^{\circ}$ and $200^{\circ} \mathrm{C}$, probably due to precipitation or solution of soluble constituents, recrystallization, or release of strains. The curve on cooling from $200^{\circ} \mathrm{C}$ to room temperature was found to be regular. After cooling to room temperature, the sample was 0.050 percent longer than the length before heating.

The expansion curves of annealed samples 1097 and 1353 were found to be regular on heating and cooling. After cooling to room temperature, these samples were only 0.001 percent longer than the lengths before heating. The coefficients of expansion of these samples are slightly less than the coefficients of expansion of the annealed samples containing 10 percent of copper and 0.4 percent of iron (table 1, C).

Table 3 gives coefficients of expansion of several annealed aluminum-iron and aluminum-copper-iron alloys investigated by Kempf [2] and Maresca [15]. The coefficients of expansion of the annealed alu-

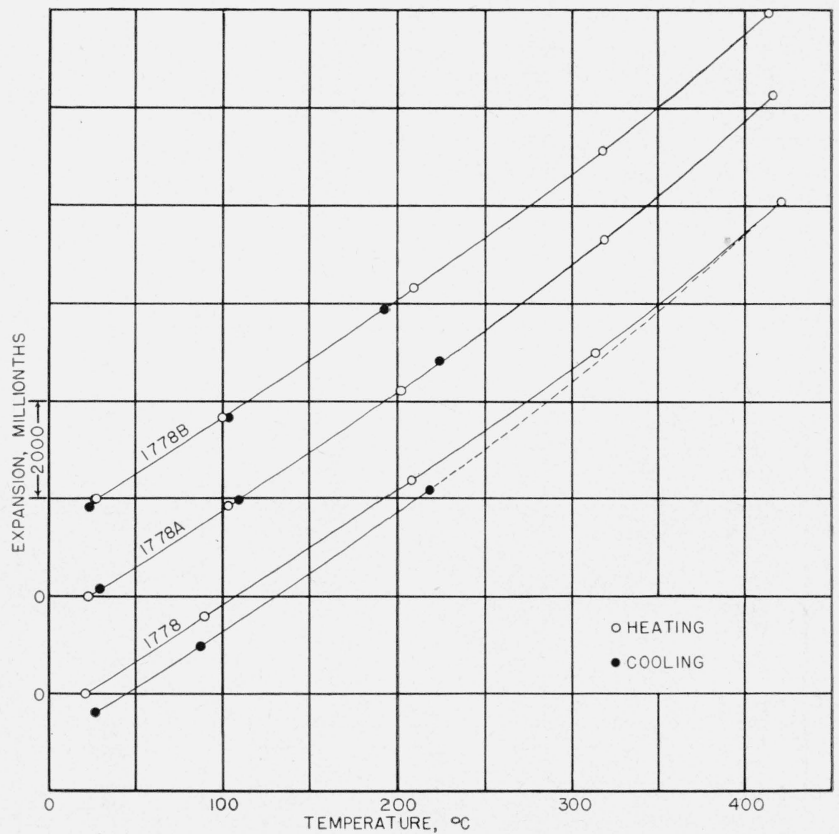

Figure 6. Linear thermal expansion (in millionths per unit length) of aluminum-copper-magnesium alloys containing 4.4 percent of copper and 1.4 percent of magnesium by weight.

Sample 1778 , solution heat-treated at $920^{\circ} \mathrm{F}\left(493^{\circ} \mathrm{C}\right)$ for $1 \mathrm{hr}$, quenched in water and aged at room temperature; $1778 \mathrm{~A}$, same treatment as sample 1778 , then aged at $700^{\circ} \mathrm{F}\left(371^{\circ} \mathrm{C}\right.$ ) for $100 \mathrm{hr} ; 1778 \mathrm{~B}$, same treatment as sample 1778 , then aged at $800^{\circ} \mathrm{F}\left(427^{\circ} \mathrm{C}\right)$ for $500 \mathrm{hr}$. 
minum-copper-iron alloys of the present investigation are about $1 \times 10^{-6}$ greater than those reported by Kempf for an alloy containing 9.9 percent of copper and 1.1 percent of iron.

In an investigation of the physical properties of aluminum alloys at elevated temperatures as one phase of research by National Advisory Committee for Aeronautics on aircraft engine materials, determinations of the linear thermal expansion of samples of rolled aluminum-copper-magnesium, aluminumcopper-nickel, aluminum-silicon-magnesium, and aluminum-copper-nickel-magnesium alloys were made. The chemical composition and heat treatment of these samples are indicated under F, G, I, and $\mathrm{J}$ of table 1.

The observations obtained on heating and cooling the samples of aluminum-copper-magnesium, aluminum - copper - nickel, aluminum - silicon-magnesium, and aluminum-copper-nickel-magnesium alloys to various temperatures between room temperature and $800^{\circ} \mathrm{F}\left(427^{\circ} \mathrm{C}\right)$ are shown in figures 6 to 9 . The expansion curves indicate that the linear thermal expansion of the samples increases with temperature. The contraction curves of the samples aged at $700^{\circ} \mathrm{F}$ $\left(371^{\circ} \mathrm{C}\right)$ and at $800^{\circ} \mathrm{F}\left(427^{\circ} \mathrm{C}\right)$ lie closer to the expansion curves than the contraction and expansion curves of the samples aged at lower temperatures.

F, G, I, and J of table 1 give coefficients of expansion and coefficients of contraction of the heattreated aluminum-copper-magnesium, aluminumcopper-nickel, aluminum-silicon-magnesium, and aluminum-copper-nickel-magnesium alloys. These

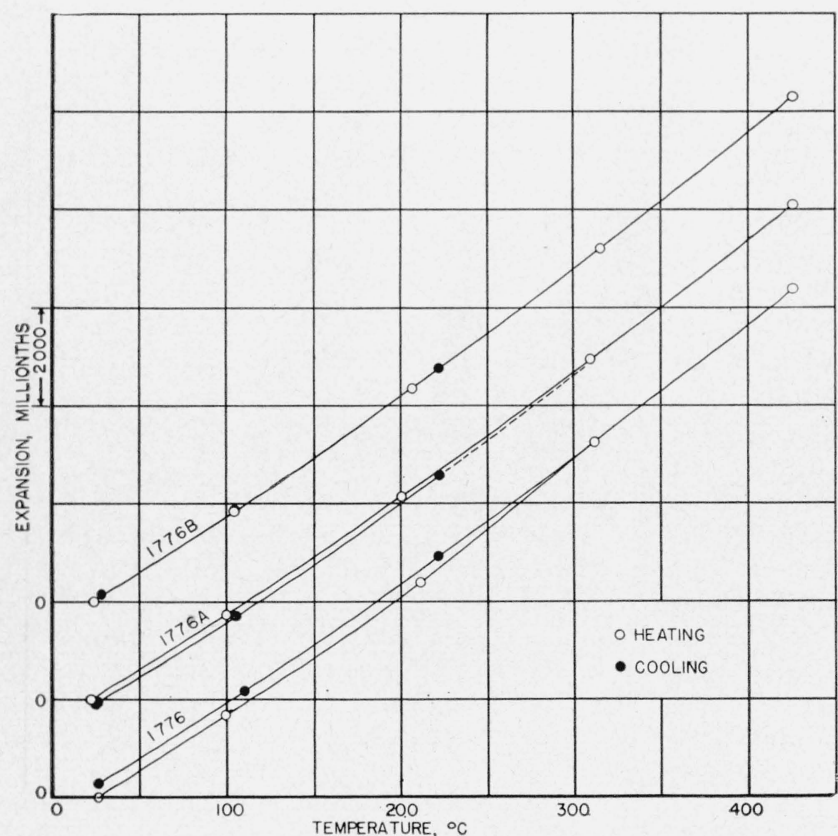

Figure 7. Linear thermal expansion (in millionths per unit length) of aluminum-copper-nickel alloys containing 4.0 percent of copper and 2.0 percent of nickel by weight.

Sample 1776, solution heat-treated at $960^{\circ} \mathrm{F}\left(516^{\circ} \mathrm{C}\right)$ for $1 \mathrm{hr}$, quenched in water, and aged at $340^{\circ} \mathrm{F}\left(171^{\circ} \mathrm{C}\right)$ for $10 \mathrm{hr} ; 1776 \mathrm{~A}$, same treatment as sample 1776 , then aged at $700^{\circ} \mathrm{F}\left(371^{\circ} \mathrm{C}\right)$ for $100 \mathrm{hr} ; 1776 \mathrm{~B}$, same treatment as sample 1776 , then aged at $800^{\circ} \mathrm{F}\left(427^{\circ} \mathrm{C}\right)$ for $500 \mathrm{hr}$. coefficients were derived from the expansion and contraction curves in figures 6 to 9 . The average difference between the coefficients of expansion of the samples aged at $700^{\circ} \mathrm{F}\left(371^{\circ} \mathrm{C}\right)$ and at $800^{\circ} \mathrm{F}$ $\left(427^{\circ} \mathrm{C}\right)$ compared to the corresponding coefficients of the samples aged at lower temperatures is $\pm 0.6 \times$ $10^{-6} / \mathrm{deg} \mathrm{C}$, but the average difference between the coefficients of contraction of the samples aged at $700^{\circ} \mathrm{F}\left(371^{\circ} \mathrm{C}\right)$ and at $800^{\circ} \mathrm{F}\left(427^{\circ} \mathrm{C}\right)$ compared

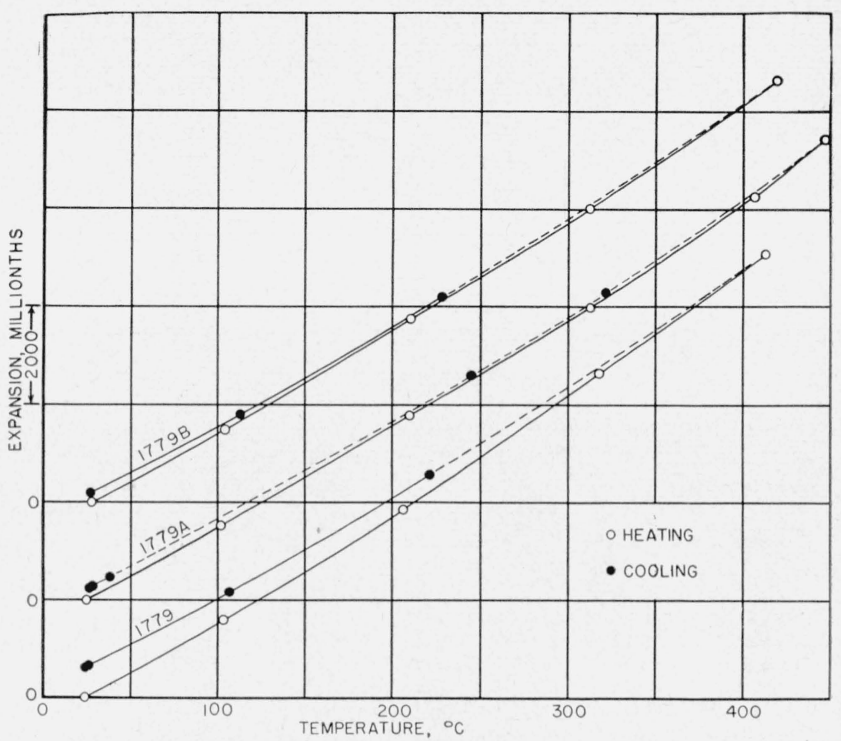

FIGURE 8. Linear thermal expansion (in millionths per unit length) of aluminum-silicon-magnesium alloys containing 12.2 percent of silicon and 1.2 percent of magnesium by weight.

Sample 1779, solution heat-treated at $960^{\circ} \mathrm{F}\left(516^{\circ} \mathrm{C}\right)$ for $1 \mathrm{hr}$, quenched in Sample 1779 , solution heat-treated at $960^{\circ} \mathrm{F}\left(516^{\circ} \mathrm{C}\right)$ for $1 \mathrm{hr}$, quenched in
water, aged at $340^{\circ} \mathrm{F}\left(171^{\circ} \mathrm{C}\right)$ for $12 \mathrm{hr} ; 1779 \mathrm{~A}$, same treatment as sample 1779 , water, aged at $340^{\circ} \mathrm{F}\left(171^{\circ} \mathrm{C}\right)$ for $12 \mathrm{hr} ; 1779 \mathrm{~A}$, same treatment as sample 1779 ,
then aged at $700^{\circ} \mathrm{F}\left(371^{\circ} \mathrm{C}\right)$ for $100 \mathrm{hr} ; 1779 \mathrm{~B}$, same treatment as sample 1779 , then aged at $800^{\circ} \mathrm{F}\left(427^{\circ} \mathrm{C}\right)$ for $500 \mathrm{hr}$.

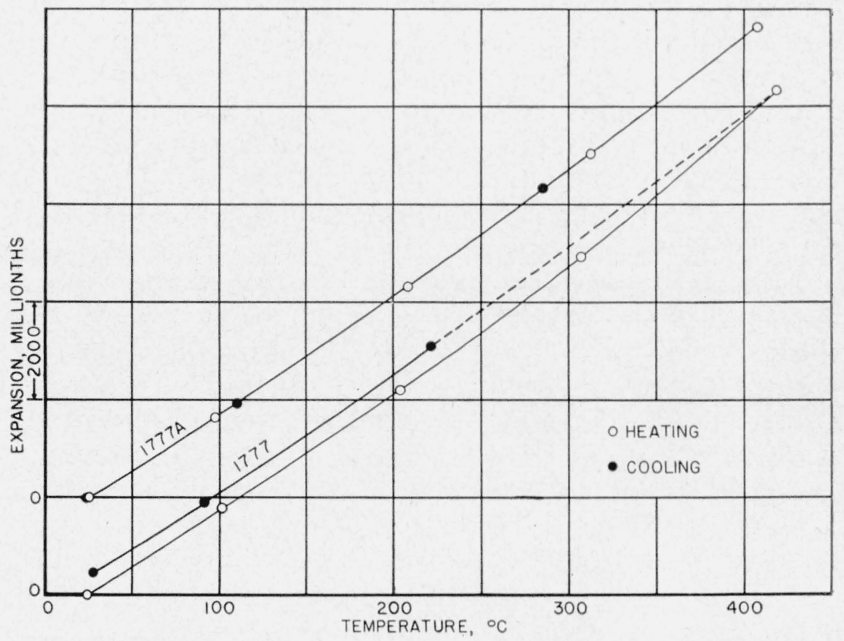

FIguRE 9. Linear thermal expansion (in millionths per unit length) of aluminum-copper-nickel-magnesium alloys containing 3.9 percent of copper, 2.1 percent of nickel, and 1.4 percent of magnesium by weight.

Sample 1777, solution heat-treated at $960^{\circ} \mathrm{F}^{\prime}\left(516^{\circ} \mathrm{C}\right)$ for $1 \mathrm{hr}$, quenched in water, aged at $340^{\circ} \mathrm{F}\left(171^{\circ} \mathrm{C}\right)$ for $10 \mathrm{hr} ; 1777 \mathrm{~A}$, same treatment as sample 1777 , then aged at $700^{\circ} \mathrm{F}\left(371^{\circ} \mathrm{C}\right)$ for $100 \mathrm{hr}$. 


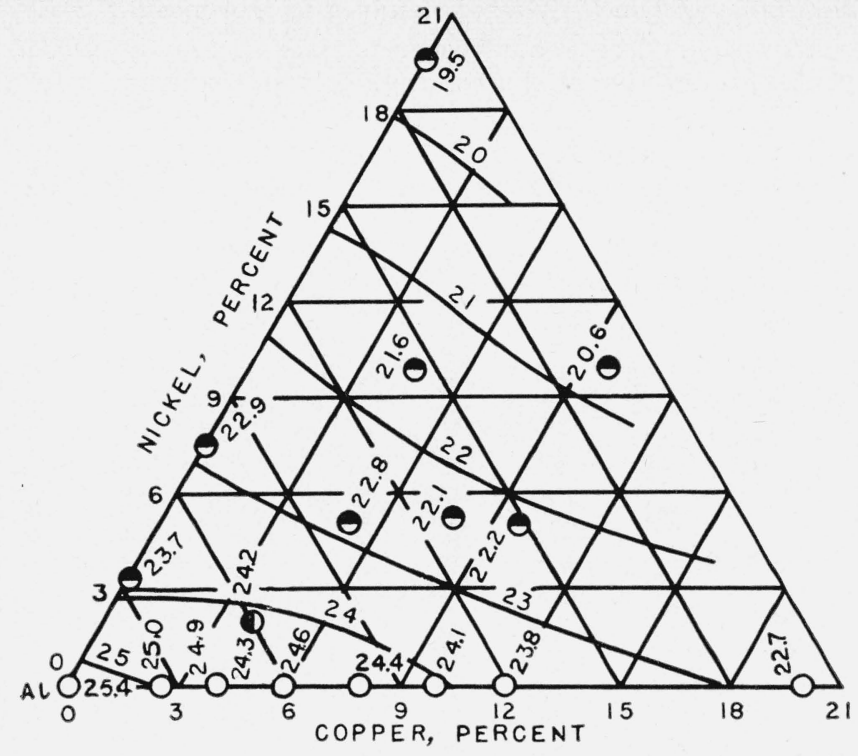

Figure 10. Portion of ternary diagram indicating the effects of composition (percentage by weight) on the coefficients of linear expansion (in millionths per degree centigrade) of annealed aluminum-copper-nickel alloys for the range $20^{\circ}$ to $300^{\circ} \mathrm{C}$.

○, From data in figure 2; , authors (24.3); Willey and Fink (24.2); $\odot$ Kempf.

to the corresponding coefficients of the samples aged at lower temperatures is only $\pm 0.2 \times 10^{-6} / \mathrm{deg} \mathrm{C}$. The coefficients of expansion of the aluminumsilicon-magnesium alloy containing 12 percent of silicon are nearly 15 percent less than those for the aluminum-copper-magnesium, aluminum-coppernickel, and aluminum-copper-nickel-magnesium alloys containing about 4 percent of copper.

The dimensional changes of the samples of aluminum-copper-magnesium, aluminum-coppernickel, aluminum-silicon-magnesium, and aluminumcopper-nickel-magnesium alloys at room temperature after heating and cooling during the thermal-expansion determinations were less for the samples aged at $700^{\circ} \mathrm{F}\left(371^{\circ} \mathrm{C}\right)$ and at $800^{\circ} \mathrm{F}\left(427^{\circ} \mathrm{C}\right)$ than for those aged at lower temperatures (last column of table 1).

Figure 10 indicates average coefficients of expansion of annealed aluminum-copper-nickel alloys for the range from $20^{\circ}$ to $300^{\circ} \mathrm{C}$. Values obtained by Kempf [2] and Willey and Fink [9] are included in the ternary diagram. Coefficients of expansion of aluminum-copper alloys were taken from the straight line $\left(20^{\circ}\right.$ to $\left.300^{\circ} \mathrm{C}\right)$ shown in figure 2 . The curves in figure 10 were derived from the data shown in this ternary diagram. Each curve (or straight line) called an isodil, ${ }^{7}$ represents a constant coefficient of expansion for various ternary compositions for a definite temperature range.

The isodils for the annealed aluminum-coppernickel alloys are nearly perpendicular to the alumi-

7 The word "isodil" was dorived in 1931 by Hidnert, from "iso" (Greek isos, meaning equal) and from the first three letters of "dilatation"

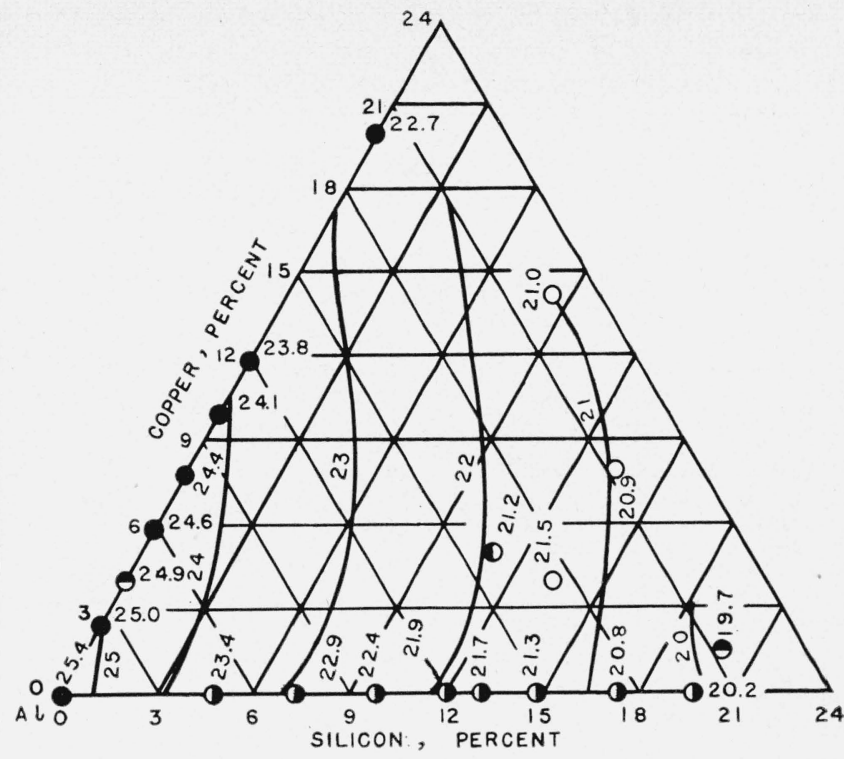

FIgure 11. Portion of ternary diagram indicating the effects of composition (percentage by weight) on the coefficients of linear expansion (in millionths per degree centigrade) of annealed or heat-treated aluminum-silicon-copper alloys for the range $20^{\circ}$ to $300^{\circ} \mathrm{C}$.

, Authors; from data in figure 2; from data in figure 3; O, Barber (1949); Maresca (1936).

num-nickel side of the ternary diagram, and indicate the effects of composition on the coefficients of expansion of these alloys.

The coefficients of expansion of the heat-treated aluminum-silicon-magnesium alloy containing about 12 percent of silicon and 1 percent of magnesium are in close agreement with the coefficients of expansion reported by Willey and Fink [9] for an annealed and a heat-treated alloy of approximately the same composition.

Table 4 gives coefficients of expansion of aluminum-copper-nickel-magnesium alloys investigated by Bollenrath [8] and Barber [12]. The mean of the coefficients of expansion of these alloys for the ranges from $20^{\circ}$ to $100^{\circ} \mathrm{C}$ and from $20^{\circ}$ to $200^{\circ} \mathrm{C}$ is $0.7 \times 10^{-6}$ smaller than the mean of the coefficients of expansion of the samples of the aluminum-copper-nickelmagnesium alloys of the present investigation for the corresponding temperature ranges. For the range from $20^{\circ}$ to $300^{\circ} \mathrm{C}$, the corresponding difference between the means of the coefficients of expansion is $0.3 \times 10^{-6}$.

Figure 11 indicates average coefficients of expansion of annealed or heat-treated aluminum-silicon-copper alloys for the range from $20^{\circ}$ to $300^{\circ} \mathrm{C}$. Values reported by Maresca [15] and Barber ${ }^{8}$ [12] are included in the ternary diagram. Coefficients of expansion of aluminum-copper and aluminum-silicon were taken from the straight lines $\left(20^{\circ}\right.$ to $\left.300^{\circ} \mathrm{C}\right)$ shown in figures 2 and 3.

${ }^{8}$ Barber reported values ranging from 20.6 to $21.6 \times 10^{-6}$ for 4 samples containing $1.0 \%$ of silicon and $5.0 \%$ of copper. The spread of the values is large, and ap parently nominal values were reported for the chemical composition. Accord. ingly, the average of his values $\left(21.2 \times 10^{-6}\right)$, indicated in figure 11 , was ignored in deriving the curves. 
TABLE 4. Coefficients of expansion of aluminum-copper-nickel-magnesium alloys by other observers

\begin{tabular}{|c|c|c|c|c|c|c|c|c|c|c|c|c|c|}
\hline \multirow{2}{*}{ Observer } & \multirow{2}{*}{ Date } & \multicolumn{6}{|c|}{ Chemical composition (by weight) } & \multirow{2}{*}{ Treatment } & \multicolumn{5}{|c|}{ A verage coefficients of expansion per degree centigrade } \\
\hline & & Al a & $\mathrm{Cu}$ & $\mathrm{Ni}$ & $\mathrm{Mg}$ & $\mathrm{Si}$ & $\mathrm{Fe}$ & & $20^{\circ}$ to $100^{\circ} \mathrm{C}$ & $23^{\circ}$ to $200^{\circ} \mathrm{C}$ & $20^{\circ}$ to $300^{\circ} \mathrm{C}$ & $20^{\circ}$ to $400^{\circ} \mathrm{C}$ & $20^{\circ}$ to $500^{\circ} \mathrm{C}$ \\
\hline Bollenrath.... & 1949 & $\begin{array}{r}\% \\
92.5\end{array}$ & $4^{\%}$ & $2^{\%}$ & $\begin{array}{r}\% \\
1.5\end{array}$ & $\%$ & $\%$ & $\begin{array}{l}\text { A nnealed at } 520^{\circ} \mathrm{C} \text { for } 24 \text { hours and } \\
\text { cooled to room temperature in } 16 \\
\text { hours. } \\
\text { Wrought, quenched from } 511^{\circ} \mathrm{C} \text { in } \\
\text { fairly hot water, and aged at } \\
\text { room temperature. } \\
\text { Same treatment as preceding, then } \\
\text { given stability heat treatment at } \\
300^{\circ} \mathrm{C} \text {. }\end{array}$ & $\begin{array}{l}23.2 \times 10^{-6} \\
21.4 \\
21.5\end{array}$ & $\begin{array}{l}23.8 \times 10^{-6} \\
22.5 \\
22.7\end{array}$ & $\begin{array}{l}24.6 \times 10^{-6} \\
23.8 \\
23.6\end{array}$ & $25.5 \times 10^{-6}$ & 26. $2 \times 10^{-6}$ \\
\hline
\end{tabular}

a By difference.

4. The isodils for the annealed or heat-treated aluminum-silicon-copper alloys are nearly perpendicular to the aluminum-silicon side of the ternary diagram, and indicate the effects of composition on the coefficients of expansion of these alloys.

Coefficients of expansion of a cast and of an annealed aluminum-copper-tin-zinc alloy containing about 2 percent of copper, 1 percent of tin, and 1 percent of zinc are given in table $1, \mathrm{~K}$. The coefficients of expansion of the annealed sample for the temperature ranges to $200^{\circ} \mathrm{C}$ are less than the coefficients of expansion of the cast sample.

A comparison of the coefficient of expansion of the sample (1205) of annealed aluminum-silicon-coppermanganese alloy ${ }^{9}$ from $20^{\circ}$ to $300^{\circ} \mathrm{C}$ with the isodils for annealed aluminum-silicon-copper alloys in figure 11 indicates that the addition of 1.1 percent of manganese and nearly 1 percent of iron to a ternary aluminum-silicon-copper alloy containing 20 percent of silicon and 3 percent of copper, reduces the coefficient of expansion.

The effects of additions of copper and nickel to aluminum-silicon alloys are indicated in figure 12, which was prepared from the data shown in table 1, M, and in figure 3 and from data by Bollenrath [8], Bungardt and Schaitberger [16], and Barber [12]. In every case except one, the additions of copper and nickel caused a decrease in the coefficients of expansion.

The effects of the addition of 4.2 percent of nickel, 3.1 percent of copper, and 1.1 percent of manganese and of 4.4 percent of nickel, 4.1 percent of copper, and 1.4 percent of molybdenum to aluminum-silicon alloys are also indicated in figure 12 . These additions caused a decrease of about $2 \times 10^{-6} / \mathrm{deg} \mathrm{C}$ in the coefficients of expansion.

${ }^{9}$ Also contains nearly $1 \%$ of iron.

Figure 12. Effects of additions of two or three elements (Cu, $\mathrm{Ni}, \mathrm{Mn}$, and Mo, percentage by weight) on coefficients of linear expansion of aluminum-silicon alloys.

Coefficients of expansion of aluminum-silicon alloys represented by straight lines from figure $3 . \bullet, \mathrm{Al}-\mathrm{Si}-\mathrm{Cu}-\mathrm{Ni}$ alloys; $\mathrm{O}, \mathrm{Al}-\mathrm{Si}-\mathrm{Ni}-\mathrm{Cu}-\mathrm{Mn}$ alloys; Al-Si-Ni-Cu-Mo alloys. 1. Cu 7.2, Ni 7.2; 2 . Cu 9.9, Ni 4.0; 3. Cu 9.8, Ni 3.9; 4 . $\mathrm{Cu} 1.0$, Ni 1.0; 5. Ni 4.4, Cu 4.1, Mo 1.4; 6. Cu 8.0, Ni 4.1; 7. Cu 4.0, Ni 4.1; 8 . Cu 4.5, Ni 1.5; 9. Ni 4.2, Cu 3.1, Mn 1.1; 10. Cu 1.5, Ni, 1 percent by weight. 1, 2, 3, 5, 6, 7, and 9, authors; 4, Barber (1949); 8, Bungardt and Schaitberger (1939); 10, Bollenrath (1933).
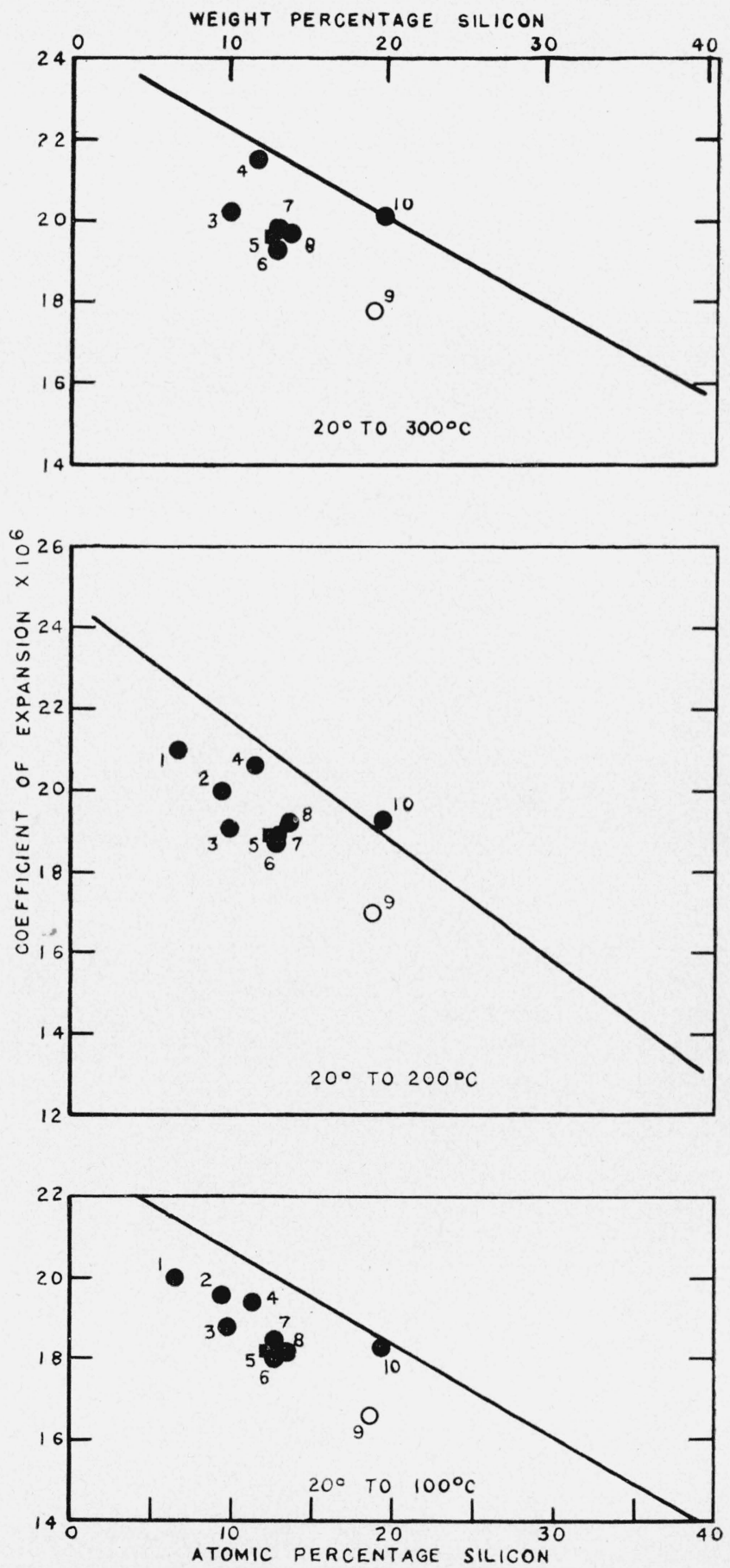


\section{References}

[1] P. Hidnert, Thermal expansion of aluminum and various important aluminum alloys, Sci. Pap. BS 19, 697 (1923-24) S497.

[2] L. W. Kempf, Thermal expansivity of aluminum alloys, Trans. Am. Inst. Mining Met. Engrs., Inst. Metals Div. 104, 308 (1933).

[3] P. Hidnert and W. Souder, Thermal expansion of solids, NBS Circular 486 (1950).

[4] F. C. Nix and D. MacNair, The thermal expansion of pure metals: copper, gold, aluminum, nickel, and iron, Phys. Rev. 60, 597 (1941).

[5] C. S. Taylor, L. A. Willey, D. W. Smith, and J. D. Edwards, The properties of high purity aluminum, Metals \& Alloys 9, 189 (1938).

[6] P. Hidnert and W. T. Sweeney, Thermal expansion of beryllium and aluminum-beryllium alloys, Sci. Pap. BS 22, 533 (1927) S565.

[7] Metals Handbook, Am. Soc. Metals, p. 1156 (1948).

[8] F. Bollenrath, Ausdehnungsmessungen an AluminiumGusslegierungen für Motorkolben, Metallwirtschaft 12, 85 (1933).
[9] L. A. Willey and W. L. Fink, An interferometer type of dilatometer, and some typical results, Am. Inst. Mining Met. Engrs., Iron and Steel Div. 162, 642 (1945).

[10] Metals Handbook, Am. Soc. Metals, p. 1159 (1948).

[11] Broniewski and Smialowski, Sur les alliages aluminiumsilicium, Rev. Mét. (Mém.) 29, 542 (1932).

[12] C. R. Barber, Some physical properties of aluminium alloys at elevated temperatures; Part 2, Linear thermal expansion, Metallurgia 41, 15 (Nov. 1949).

[13] W. Broniewski and L. Sliwowski, Sur les alliages antimoine-étain, Rev. Mét. (Mém.) 25, 312 (1928).

[14] Metals Handbook, Am. Soc. Metals, p. 1166 (1948).

[15] C. A. Maresca, Dilatazione della leghe leggere per stantuffi di motori a scoppio alle temperature di funzionamento, L'Industria Meccanica 18, 1 (1936).

[16] W. Bungardt and G. Schaitberger, Über die thermische Ausdehnung von Gleitlager-Legierungen, Z. Metallkunde 31, 240 (1939).

Washington, July 18, 1951. 